\title{
THE STUDY OF THE POSSIBILITY OF COMBINING FRESHWATER FISH WITH DUCK MEAT IN MEAT- CONTAINING SEMI-FINISHED PRODUCTS
}

\author{
Nataliia Bozhko \\ Department of technology of milk and meat \\ Sumy National Agricultural University \\ 160 G. Kondratieva str., Sumy, Ukraine, 40021 \\ natalybozhko@ukr.net \\ Vasyl Tischenko \\ Department of technology of milk and meat \\ Sumy National Agricultural University \\ 160 G. Kondratieva str., Sumy, Ukraine, 40021 \\ tischenko_1958@ukr.net \\ Vasil Pasichnyi \\ Department of technology of meat and meat products \\ National University of Food Technologies \\ 68 Volodymyrska str., Kyiv, Ukraine, 01601 \\ Pasww1@ukr.net \\ Polumbryk Manyefa \\ Department of technology of meat and meat products \\ National University of Food Technologies \\ 68 Volodymyrska str., Kyiv, Ukraine, 01601 \\ manefaiv2208@ukr.net \\ Oleksandra Haschuk \\ Department of technology of meat and meat products \\ National University of Food Technologies \\ 68 Volodymyrska str., Kyiv, Ukraine, 01601 \\ ohaschuk@ukr.net
}

\begin{abstract}
It is an urgent direction of studies to ground a possibility of combining different types of raw materials at producing semi-products.

It is prospective in creating new types of products to combine white silver carp and silver crucian and regional duck in recipes of meat-containing semi-products for raising their functional and technological indices and biological effectiveness at preserving quality organoleptic characteristics in the traditional technology of meat-containing cut semi-products. There were elaborated recipes of meat-containing semi-products and conducted experimental studies of developed products with analyzing results that prove a possibility of combining duck meat and freshwater fish in recipes of meat-containing semi-products by the complete replacement of beef and pork in recipes. There were studied functional-technological indices of model forcemeats, realized the organoleptic assessment of meat-containing semi-products and their correspondence to standard requirements to this segment of products, proved microbiological safety of obtained products. The biological value of a sample of meat-containing semi-products with optimal parameters, namely the amino acid composition, including the content of replaceable and irreplaceable amino acids was studied, amino acid score was calculated, ratios of saturated, monounsaturated and polyunsaturated fatty acids were established.

The obtained experimental data prove the expedience of combining fish and meat raw materials for creating high quality and healthy products.
\end{abstract}

Keywords: meat-containing semi-product, freshwater fish, duck meat, biological value. 


\section{Introduction}

It is an important question in the meat-processing industry to improve the quality of ready products taking into account changeability of the composition and properties of raw materials [1]. The rational combination of traditional raw materials and the use of new types of them become an urgent task for obtaining high quality products, synchronously gaining economic efficiency.

The last years there is observed a tendency of continuous increase of a number of poultry in the world, artificial breeding of freshwater fish becomes widespread that makes these types of raw materials promising sources of full-value protein for developing new types of combined products [2-4].

The study of the chemical composition of duck meat of different breeds and types of industrial fish, bred in Ukraine, demonstrates the high content of full-value proteins in raw materials, presence and optimal ratio of saturated and unsaturated fatty acids [5-10]. The biological value of meat of waterfowl duck and freshwater fish allows to talk about prospects of using them in recipes of combined meat-fish products for developing products with the high biological value and prophylactic destination [11-14].

Functional-technological properties of combined semi-products with waterfowl poultry are not inferior to traditional analogs $[15,16,27]$, and quality characteristics of meat-containing products using freshwater fish correspond to requirements, regulated by respective standards [17, 18].

But a possibility of combining waterfowl poultry and freshwater fish in mixed stuffing was not studied that is why it is an urgent task to create new meat-containing semi-products that would contain duck and regional hydrobionts (river fish).

That is why the main aim of the studies was to study functional-technological parameters and biological efficiency, microbiological safety and organoleptic characteristics of developed meat-containing cut semi-products that allow to widen the assortment of high-quality food products.

\section{Materials and Methods}

Regional "home cutlets" were chosen as a recipe of an analogue for grounding a possibility of replacing the main meat raw material for non-traditional one for meat-containing products. They are produced of beef and pork, adding wheat bread, onion, eggs, water and spices [19].

Forcemeat of Pekin duck, white silver carp and silver crucian, received after separating meat from bones and comminuting on a roll with orifices diameter 2-3 $\mathrm{mm}$ was used for the studies.

Forcemeats of duck and silver carp were used for the recipe of sample 1 instead of pork and beef, for recipe 2 forcemeat of duck and silver crucian was used instead of beef and pork in equal amounts, namely $61 \%$. Other recipe components didn't change. Forcemeat for cutlets was prepared by the technological scheme (Fig. 1).

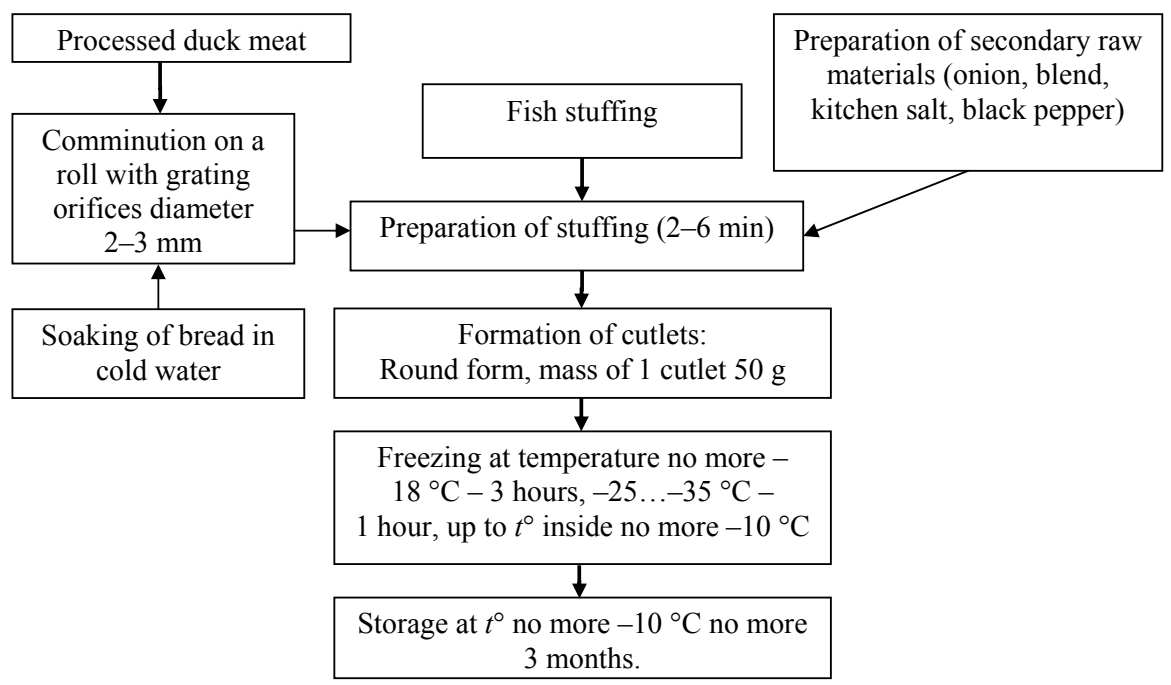

Fig. 1. Technological scheme of producing cut semi-products 
The functional-technological properties (water-retaining, water-binding, emulsifying abilities, emulsion stability) according to standard methods [21] and biological value were determined in model samples of meat-containing cut semi-products.

The water-binding capacity of forcemeat was determined by the pressing method [20]. Samples of $300 \mathrm{mg}$ were weighted with the absolute error $1 \mathrm{mg}$. Then they were placed in a polyethylene disk, transferred on a disk of filter paper. Filter paper was placed on a glass plate in such a way that a forcemeat batch is above.

The polyethylene disk was covered by the plate, and a load with mass $1 \mathrm{~kg}$ was put on it. The pressing duration is $10 \mathrm{~min}$. After ending of pressing, an area of a water spot is outlined by a pencil and an area of internal and external spots is determined by a planimeter. In parallel the mass share of moisture is determined in the studied sample by drying in a drying chamber at temperature $105^{\circ} \mathrm{C}$ to the constant mass.

The water-binding capacity of forcemeat $\left(\mathrm{WBC}_{\mathrm{a}}\right)$, as a mass share of moisture (relative to the total content of moisture in a batch), remained in a sample after pressing, was determined by (1):

$$
\mathrm{WBC}_{\mathrm{a}}=\left[\left(\frac{(\mathrm{B}-\mathrm{m})}{100}-8,4 \mathrm{~S}\right) / \mathrm{m}\right] \cdot 100 \%,
$$

where $\mathrm{m}$ - mass of the batch, mg; B - mass share of moisture in the batch, $\%$; $\mathrm{S}$ - area of the wet spot, mg.

The water-retaining capacity of forcemeat was determined as a difference between the mass share of moisture in forcemeat and amount of moisture, separated at thermal processing.

The batch of accurately comminuted meat with mass $4-6 \mathrm{~g}$ was evenly put by a glass stick on the internal surface of the wide part of a milk fat-measurer. It was hermetically closed by a cork and placed the narrow part down on the water bath at boiling temperature for $15 \mathrm{~min}$, after that the mass share of separated water is determined by a number of points on the scale of the fat-measurer.

The water-retaining capacity of meat (\%) was determined by (2):

$$
\mathrm{WRC}=\mathrm{B}-\mathrm{WSC} \text {, }
$$

where WSC - water-separating capacity of meat (\%). WRC was determined by (3):

$$
\mathrm{WRC}=\mathrm{a} \cdot \mathrm{n} \cdot \mathrm{m}^{-1} \cdot 100
$$

where B - total mass share of moisture in the batch, \%; a - value of a point of the fat-measurer; $\mathrm{a}=0,01 \mathrm{~cm}^{3} ; \mathrm{n}$ - number of points on the scale of the fat-measurer; $\mathrm{m}$ - batch mass, $\mathrm{g}$.

For determining the emulsifying capacity (EC) the following methodology was used [20]. The forcemeat batch with mass $7 \mathrm{~g}$ was suspended in $100 \mathrm{~cm}^{3}$ of water in a homogenizer at turn frequency $66,6 \mathrm{~s}^{-1}$ during $60 \mathrm{~s}$. Then added $100 \mathrm{~cm}^{3}$ of refined sunflower oil and the mixture was emulsified in the homogenizer at turn frequency $1500 \mathrm{~s}^{-1}$ during $5 \mathrm{~min}$. After that the emulsion was poured in 4 calibrated centrifuged test-tubes and centrifuged at $500 \mathrm{~s}^{-1}$ during $10 \mathrm{~min}$. Then the volume of emulsified oil was determined. EC was determined by (4), \%:

$$
\mathrm{EC}=\mathrm{V}_{1} / \mathrm{V} \times 100
$$

where $\mathrm{V}_{1}$ - volume of emulsified oil, $\mathrm{cm}^{3} ; \mathrm{V}$ - total volume of oil, $\mathrm{cm}^{3}$.

The emulsion stability was determined by heating at temperature $80{ }^{\circ} \mathrm{C}$ during $30 \mathrm{~min}$ and cooling by water during $15 \mathrm{~min}$. [23]. Then 4 calibrated centrifuged test-tubes were filled with the emulsion and centrifuged at $500 \mathrm{~s}^{-1}$ during $5 \mathrm{~min}$. Then the volume of the emulsified circle was determined. The emulsion stability ( $\%$ ) was determined by (5): 


$$
\mathrm{ES}=\mathrm{V}_{1} / \mathrm{V}_{2} \times 100
$$

where $\mathrm{V}_{1}$ - volume of emulsified oil, $\mathrm{cm}^{3} ; \mathrm{V}_{2}$ - total volume of the emulsion, $\mathrm{cm}^{3}$.

Determination of the quality of samples of semi-products was realized by the organoleptic method. At the visual examination of samples there were assessed their outlook, color, smell, taste, outlook on a cut, consistence, juiciness. The assessment was realized by 5 -point scale. The gustatory commission was made of 10 experts, among which there were professional technologists and young scientists.

The number of mesophilic aerobic and facultative anaerobic microorganisms was determined by the following methodology [21]. $10 \mathrm{~g}$ of each sample in sterile conditions were put in a packet for the homogenizer and added with $90 \mathrm{ml}$ of peptone-salt broth. The sample was homogenized using a bagmixer during 60 seconds at $20^{\circ} \mathrm{C}$.

$10 \mathrm{~cm}^{3}$ of the homogenized solution, based on ready meat-fish semi-products were taken of a sample, prepared for the analysis, by a sterile tube or pipette and put in a sterile test-tube. The test-tube with the taken product was placed in the water bath with the temperature near $50{ }^{\circ} \mathrm{C}$. Water in bath was heated to $30^{\circ} \mathrm{C}$ within the product. The test-tube with the product at the given temperature was kept on the water bath with temperature $(95 \pm 1){ }^{\circ} \mathrm{C}$ within the test-tube with the product during $20 \mathrm{~min}$.

The number of MAFAnM in $1 \mathrm{~g}\left(\mathrm{~cm}^{3}\right)$ was determined by inoculating successive solutions in Petri dishes by the deep method. Dilutions were selected for 15-300 colonies grow in inoculations on Petri dishes.

For pouring inoculations in Petri dishes, there were used agarized mediums for cultivating mesophiic aerobic and facultative anaerobic microorganisms. Inoculations were thermostated at temperature $(30 \pm 1){ }^{\circ} \mathrm{C}$ during 72 hours.

After thermostating Petri dishes with 15-300 grown colonies were selected. The recalculation of MAFAnM number for $1 \mathrm{~g}\left(\mathrm{~cm}^{3}\right)$ was realized depending on type of a studied product by (6):

$$
\mathrm{X}=\mathrm{a} \times 10^{\mathrm{n}} \frac{\left(\mathrm{V}_{\mathrm{pr}}+\mathrm{V}_{\mathrm{water}}\right)}{\mathrm{V}_{\mathrm{pr}} \times \mathrm{g}},
$$

where $\mathrm{X}$ - number of colonies in $1 \mathrm{~g}(\mathrm{~cm})$; a - number of colonies, grown in dishes; $\mathrm{n}$ - degree of tenfold dilutions in dishes; $\mathrm{V}_{\text {water }}$ - mass (volume) of water, added to a pot; $\mathrm{V}_{\mathrm{pr}}$ - mass (volume) of the product, put into the pot, $\mathrm{cm}^{3} ; \mathrm{g}-$ mass (volume) of the sowing material, put in a dish, $\mathrm{g}$.

Revelation of BCBG (coliform bacteria) was conducted using Kessler medium [20], that the solution with the primary dilution of semi-products was dipped in. Inoculations were thermostated at temperature $(36 \pm 1){ }^{\circ} \mathrm{C}$ during 24 hours. Inoculations were made of test-tubes with signs of the growth (color change, gas-creation, muddiness) on Endo medium. Preparations were made of colonies, typical for BCBG (red with metal luster or without it, rose and light-rose), colored by Gram and microscoped. At revealing gram-negative non-spore bacilli in preparations, the test for gas creation in a semi-liquid medium with glucose was made. The result after incubation at temperature $(37 \pm 1){ }^{\circ} \mathrm{C}$ in $6-8$ hours was taken into account. At revealing gas creation on the medium with glucose, a conclusion about BCBG in outwashes was made.

Determination of the content of amino acids in semi-products was realized by the method of ion-changing column chromatography using the amino acid analyzer «BIOTRONIK» (Germany). The content of bound irreplaceable and replaceable amino acids is calculated in $\mathrm{g}$ for $100 \mathrm{~g}$ of the product [22]. For preparing samples, the batch with mass $0,1 \mathrm{~g}$ was put in the test-tube with the closed cork, poured with $10 \mathrm{~cm}^{3}$ of distilled water and $10 \mathrm{~cm}^{3}$ of concentrated saline acid. The testtube was hermetically corked up and put in a drying-frying chamber with temperature $130{ }^{\circ} \mathrm{C}$ for 8 hours. The obtained hydrolysate was filtered through a wadding filter and poured by 3 volumes of distilled water. The obtained solution was transferred in a porcelain dish and evaporated on an electric stove to volume $0,5 \ldots 1,0 \mathrm{ml}$. The obtained sample was diluted by distilled water and filtered through a paper filter in $50 \mathrm{ml}$ test-tube and a filter was washed till a test-tube was filled with 35-40 $\mathrm{ml}$. The quantitative determination of amino acids was made by taking $1 \mathrm{ml}$ and adding 
$1 \mathrm{ml}$ of a buffer solution with $\mathrm{pH}=2,2$. The obtained sample was passed through a membrane filter with pores diameter $0,45 \mathrm{mcm}$. $50 \mathrm{mcl}$ of the cleaned sample were taken and put in a chromatographic ion-exchanging column of the analyzer. After finishing the analysis, the obtained chromatogram was deciphered and areas of peaks of each amino acid were calculated by the method of external standard.

Determination of YBS of semi-products was realized by the method of gas chromatography using the automated gas chromatograph Cupol-55 (electromechanical plant "Cupol”, Russia) [23] (Fig. 2). For determining YBS of semi-products, a sample was prepared by extracting lipids. The mixture of chloroform-methanol (1:2) and water in ratios 30:3 $\mathrm{ml}$ were added to $6 \mathrm{~g}$ of the sample and homogenized during $2 \mathrm{~min}$ at $20^{\circ} \mathrm{C}$.

Homogenisat was centrifuged, the residue was re-extracted by $38 \mathrm{ml}$ of the mixture of chloroform:methanol:water $(1: 2: 0,8)$ in the homogenizer during 2 min. Forcemeat was separated by centrifuging, combined super-natants were solved in $20 \mathrm{ml}$ of chloroform and $20 \mathrm{ml}$ of water. Water-methanol and chloroform phase were separated by centrifuging. The low layer of chloroform was concentrated on a rotor evaporator at temperature $30-35^{\circ} \mathrm{C}$. The residue was solved in $10 \mathrm{ml}$ of chloroform.

For saponification of fats there were combined $10 \mathrm{~g}$ of fat, $3,9 \mathrm{~g}$ of $\mathrm{KOH}$ and $50 \mathrm{ml}$ of $96 \%$ ethanol. During 2-3 hours the mixture was heated with a reverse refrigerator in the atmosphere of inert gas, periodically shaking a flask. After ending of this time, the mixture was cooled, solved by distilled water (1:1), neutralized by $10 \% \mathrm{H}_{2} \mathrm{SO}_{4}$ to $\mathrm{pH}=7$ acidified to $\mathrm{pH}=2$. The mixture was extracted in a dividing crater with volume $200 \mathrm{ml}$ by sulfuric ether, the procedure was repeated trice in ratio 1:0,5. Combined ether tinctures were twice washed by distilled water, then dried by waterless sulfuric sodium.

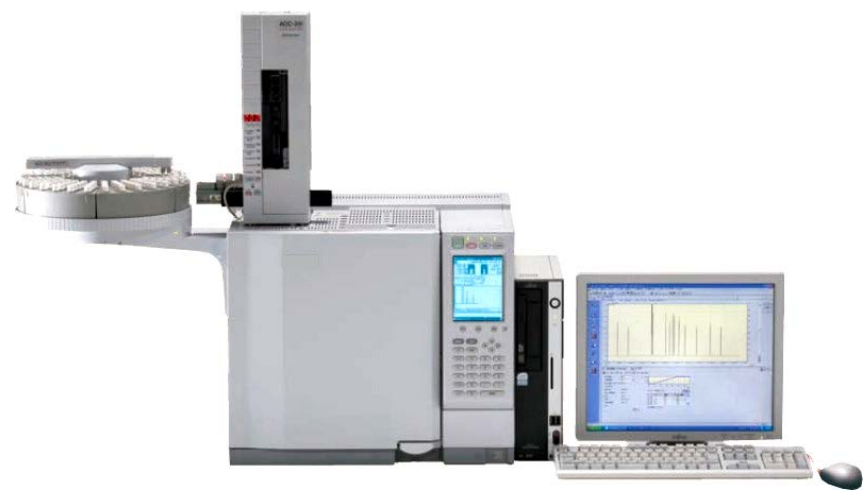

Fig. 2. Chromatograph Cupol-55 (Russia)

The extract was concentrated on the rotor evaporator at temperature no higher than $40{ }^{\circ} \mathrm{C}$. After heating on the water bath during $50 \mathrm{~min}$, the extract was diluted by water in ratio 1:1. Then hexane tinctures were obtained. Hexane was stewed on the rotor evaporator, there were obtained chromatographically pure methyl ethers of fatty acids, solved in hexane and chromatographed on the chromatograph Cupol-55 (Russia) on the column SP 2560 (USA) with length $100 \mathrm{~m}$.

The amino acid score (\%) was calculated by (7) [24]:

$$
\mathrm{AS}=\mathrm{AA}_{\mathrm{x}} / \mathrm{AA}_{\mathrm{s}} \times 100
$$

where AS - amino acid score; AAx - amino acid in the studied protein AAs - the same amino acid in the standard protein or by the scale. The amino acid scale of FAO/WHO was used as a standard for calculating the amino acid score [24].

The absolute error of measurements was determined using Student criterion, reliable interval $\mathrm{P}=0,95$, number of repeats in determinations $3-4$, number of parallel tests of experimental samples -3 . 


\section{Results}

The study of main functional-technological parameters of model forcemeats of cut semi-products with duck and freshwater fish demonstrated that both experimental samples were not inferior to the control one and had higher values by practically all parameters. Among the studied samples, model forcemeat with silver crucian had higher indices, comparing with the one with silver carp and control product as to the moisture content, $\mathrm{WRC}_{\mathrm{a}}$ and $\mathrm{WRC}_{\mathrm{m}}$, forcemeat emulsifying capacity, emulsion stability.

As a result of the organoleptic assessment, it was established, that developed meat-containing cut semi-products differed by lower indices only by color from the control sample. It indicates the expedience of introducing additional natural spices for giving a product its proper color.

The studies of microbiological safety in samples of cutlets with duck and freshwater fish by MAFAnM number demonstrated, that the value of these parameters doesn't exceed a norm [20]. Bacteria of the colon bacillus group were not revealed in any sample.

The study of the biological value of protein of the meat-containing semi-product with duck and silver crucian demonstrated the presence of all irreplaceable amino acids in a sample. The combination of waterfowl poultry and freshwater fish allows to increase the content of such amino acids as leucine, phenylalanine-tyrosine, threonine, which biological value cannot be overestimated [26].

The analysis of the protein quality by the amino acid score (AS) demonstrated that this index was higher than $100 \%$ in all essential amino acids, except methionine. The highest amino acid score was observed in threonine.

As a result of using freshwater fish and duck meat in the recipe, the biological efficiency of lipids of a meat-containing cut semi-product, characterized by the normative ratio of $\omega-3$ and $\omega-6$ PUFA [27, 28], was 1:7. It testifies to the fact that at combining Pekin duck and freshwater fish, namely silver crucian in the composition of frozen cut meat-containing semi-products, it is possible to produce biologically full-value products with high qualitative characteristics.

The obtained results indicate that the recipe of meat-containing semi-products with adding silver crucian has better functional-technological parameters. The content of moisture in this sample is at the level of $82,42 \pm 1,16 \%$ that is by $16 \%$ higher comparing with the control sample and by $13,17 \%$ higher comparing with the sample with silver carp.

\section{Conclusions}

The conducted studies proved the expedience of combining duck meat and freshwater fish in recipes of meat-containing cut semi-products. The proposed variants of recipes allowed to raise functional-technological indices of model forcemeats of semi-products at the expanse of the successful combination of components.

The results of sensory assessment of meat-containing cut semi-products demonstrated that experimental samples of cutlets are not inferior to classic ones by the total summary mark that was 4,58-4,62 points.

The study of the biological value of proteins and lipids of meat-containing cut semi-products with duck and silver crucian demonstrated that the combination of regional sources of aquaculture, waterfowl poultry with traditional types of meat and vegetable raw materials can be effective for raising the biological value of this type of products.

The conducted studies indicate perspectives of manufacturing semi-products with adding fish raw materials that allows to enrich the food ration of consumers with nutritive components and to widen the ration of people with certain limitations of consuming beef and pork.

\section{References}

[1] Lysenko, H. P. (2017). Suchasnyi stan i perspektyvy rozvytku miasopererobnoi haluzi. Visnyk ahrarnoi nauky, 1, 72-75.

[2] Myniv, R. M. (2015). Perspektyvy rozvytku miasnoho ptakhivnytstva. Naukovyi Visnyk LNUVMBT im. S. Z. Hzhytskoho, 17 (1), 233-238.

[3] Donchevska, R. (2015). Rozvytok rybnoho hospodarstva Ukrainy. Tovary i rynky, 1, 28-40. 
[4] Rynok miasa ptytsi v Ukraini (2017). Available at: http://www.poultryukraine.com/data/file/ analytics/ptica_yanvar_maj_2017.pdf

[5] Jaturasitha, S., Srikanchai, T., Kreuzer, M., Wicke, M. (2008). Differences in Carcass and Meat Characteristics Between Chicken Indigenous to Northern Thailand (Black-Boned and Thai Native) and Imported Extensive Breeds (Bresse and Rhode Island Red). Poultry Science, 87 (1), 160-169. doi: https:// doi.org/10.3382/ps.2006-00398

[6] Huda, N., Putra, A. A., Ahmad, R. (2011). Potential Application of Duck Meat for Development of Processed Meat Products. Current Research in Poultry Science, 1 (1), 1-11. doi: https://doi.org/10.3923/crpsaj.2011.1.11

[7] Baeza, E. (2006). Effects of genotype, age, and nutrition on intramuscular lipids and meat quality. Proceeding of the Symposium COA/INRA Scientific Cooperation in Agriculture, 79-82.

[8] Mohanty, B. P., Mahanty, A., Ganguly, S., Mitra, T., Karunakaran, D., Anandan, R. (2017). Nutritional composition of food fishes and their importance in providing food and nutritional security. Food Chemistry. doi: https://doi.org/10.1016/j.foodchem.2017.11.039

[9] Lisovoy, V. V. (2010). Maloispolzuemaya prudovaya ryba i otkhody ee pererabotki tovarnoy prudovoy ryby - tsennoe syre dlya polucheniya belkovoy dobavki. Novye tekhnologii, 3, 11-15.

[10] Lebska, T. (2014). Kharchova tsinnist koropa Cyprinus Carpio i tovstolobyka Hypophtalmichthys spp osinnoho vylovu. Tekhnika i tekhnolohiyi APK, 5, 12-15.

[11] Pasichnyi, V. N. (2014). Kulinarnye polufabrikaty iz myasa ptitsy pishchevoy tsennosti. Vestnik Almatinskogo tekhnologicheskogo universiteta, 3, 14-18.

[12] Strashynskiy, I., Fursik, O., Pasichniy, V., Marynin, A., Goncharov, G. (2016). Influence of functional food composition on the properties of meat mince systems. Eastern-European Journal of Enterprise Technologies, 6 (11 (84)), 53-58. doi: https://doi.org/10.15587/1729-4061.2016.86957

[13] Lilishentseva, A. N. (2008). Perspektivnye napravleniya sozdaniya kombinirovannykh produktov. Pishchevaya promyshlennost, 2, 16-19.

[14] Brandstetter, S., Rüter, J., Curbach, J., Loss, J. (2015). A systematic review on empowerment for healthy nutrition in health promotion. Public Health Nutrition, 18 (17), 3146-3154. doi: https://doi.org/10.1017/ s1368980015000270

[15] Kumar, R. (2015). Quality and shelf life evaluation of nuggets prepared from spent duck and spent hen meat. Explor Anim Med Res, 5 (2), 176-182.

[16] Vijayakumar, K. S. (2006). Quality and storage stability of enrobed duck cutlet. Journal of food science and technology-mysore, 43 (2), 154-156.

[17] Pasichnyi, V. M. et. al. (2015). Udoskonalennia tekhnolohiyi miaso-rybnykh napivfabrykativ. Tekhnolohiya vyrobnytstva i pererobky produktsiyi tvarynnytstva, 1, 116-120.

[18] Matsuk, Y. A., Suprun, E. M., Ischenko, N. V., Pasichniy, V. M. (2016). The theoretical and applied aspects production of the meat and fish products. Scientific Messenger of LNU of Veterinary Medicine and Biotechnology, 18 (2 (68)), 171-173. doi: https://doi.org/10.15421/nvlvet6836

[19] DSTU 4437-2005. Vydannia. Napivfabrykaty miasni ta miaso-roslynni posicheni (2006). Kyiv, 24.

[20] Antipova, L. V. (2001). Metody issledovaniya myasa i myasnykh produktov. Moscow: Kolos, 576.

[21] DSTU 8446:2015. Produkty kharchovi. Metody vyznachennia kilkosti mezofilnykh aerobnykh ta fakultatyvno-anaerobnykh mikroorhanizmiv (2015). Kyiv, 16.

[22] DSTU ISO 13903:2009. Kormy dlia tvaryn. Metod vyznachennia vmistu aminokyslot (2009). Kyiv, 18.

[23] DSTU ISO 15885/IDF 184:2008. Zhyr molochnyi. Vyznachennia zhyrnokyslotnoho skladu metodom hazoridynnoi khromatohrafiyi. Metody ekstrahuvannia lipidiv ta liporozchynnykh spoluk (2011). Kyiv, 12.

[24] Rogov, I. A. (2007). Khimiya pishchi. Moscow: Kolos, 15-17.

[25] Dobrobabina, L. B. (2008). Naukovi osnovy kompleksu tekhnolohiyi kharchovykh produktiv z hidrobiontiv. Odessa: ONAKhT, 36.

[26] Mohanty, B., Mahanty, A., Ganguly, S., Sankar, T. V., Chakraborty, K., Rangasamy, A. et. al. (2014). Amino Acid Compositions of 27 Food Fishes and Their Importance in Clinical Nutrition. Journal of Amino Acids, 2014, 1-7. doi: https://oi.org/10.1155/2014/269797

[27] Bozhko, N., Tischenko, V., Pasichnyi, V., Marynin, A., Polumbryk, M. (2017). Analysis of the influence of rosemary and grape seed extracts on oxidation the lipids of peking duck meat. Eastern-European Journal of Enterprise Technologies, 4 (11 (88)), 4-9. doi: https://doi.org/10.15587/1729-4061.2017.108851

[28] Fedorova, D. V., Karpenko, P. O., Vasylieva, O. O. (2017). Doslidzhennia zhyrnokyslotnoho skladu lipidiv sukhykh rybo-roslynnykh napivfabrykativ. Kharchova nauka i tekhnolohiya, 11 (3), 61-70. doi: https://doi.org/10.15673/fst.v11i3.608 